Evangelisches Studienwerk e.V.
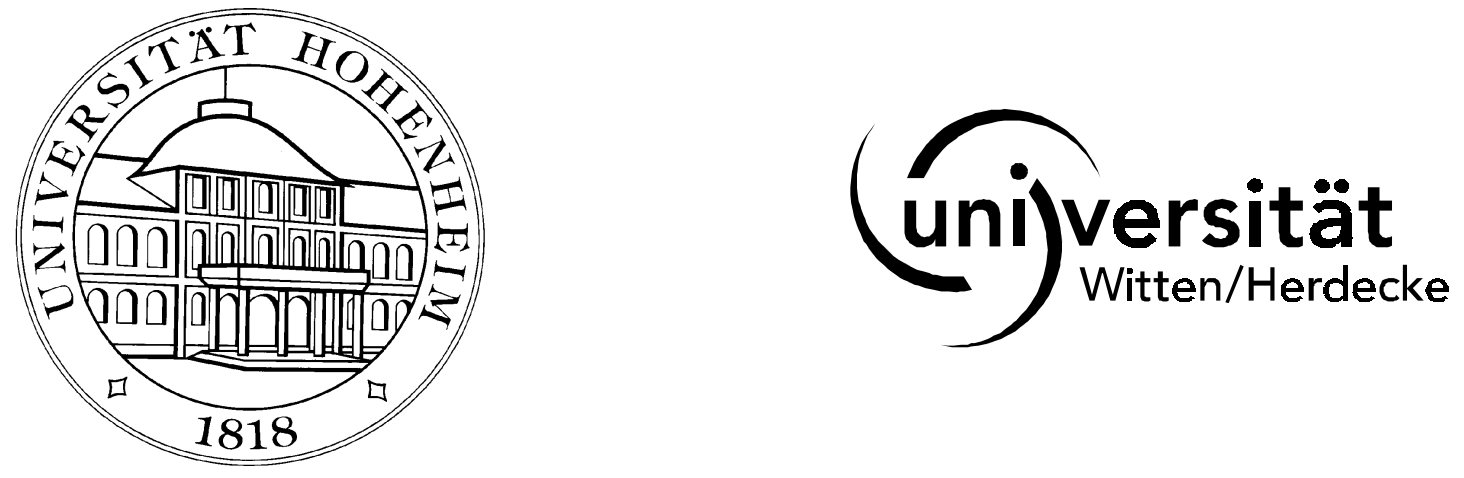

Schriftenreihe des Promotionsschwerpunkts

Makroökonomische Diagnosen und Therapien der Arbeitslosigkeit

No. $15 / 2000$

Some Cambridge Reactions to The General Theory:

David Champernowne and Joan Robinson on

Full Employment

by

Mauro Boianovsky

Stuttgart-Hohenheim

ISSN 1436 - 1655 


\section{Some Cambridge Reactions to The General Theory: David Champernowne and Joan Robinson on Full Employment}

by

\section{Mauro Boianovsky}

Departamento de Economia

Universidade de Brasília

Brasília - DF - 70910-900

Brazil

boianovs@unb.br

Lecture given at the University of Hohenheim, September 5, 2000.

I am most grateful to Geoff Harcourt for his comments on a first draft of this paper and to Harald Hagemann for his helpful discussion at the History of Economics Society conference (Vancouver, June 2000). A research grant from CNPq (Brazilian Research Council) is gratefully acknowledged. This paper is part of a PROBRAL cooperation project between the University of Brasilia and the University of Hohenheim supported by CAPES and DAAD. 
"The great ideology-bearing concept in the General Theory is Full Employment itself.” (Robinson, [1962a] 1964, p. 85)

\section{Introduction}

It is well-known that, soon after the publication of The General Theory, Maynard Keynes expressed dissatisfaction with his treatment of the concepts of "involuntary unemployment" and "full employment" in chapter 2 of his book. In replying to Jacob Viner's (1936) critical review, Keynes ([1937] 1973, p. 110) agreed that "this part of my book is particularly open to criticism". Keynes's analysis of the labour market was also extensively criticized at the time by some young economists at Cambridge: David Champernowne (1936), who was a former supervision pupil of his, and Joan Robinson (1937a), who played a major role in the famous "Cambridge Circus" in the early 1930s. In contrast to Viner (and to the negative reactions put forward in Cambridge by D. H. Robertson and A. C. Pigou; see Presley, 1986), Champernowne and Robinson very much endorsed the analytical framework of The General Theory, but they diverged, albeit for different reasons, from Keynes's approach to the dynamics of money and real wages.

One of the corollaries of Keynes's (1936) treatment of the concept of full employment is the absence of a conflict between relatively high employment (at more than minimum unemployment) and price level stability. Although Keynes referred to the effects of higher levels of activity on higher price and money-wage levels (which he called "semi-inflation"; see 1936, p. 301), the notion that a high level of employment in the transition to minimum unemployment could be associated with a positive rate of change of prices and money-wages was foreign to his thought at the time of writing The General Theory (see Phelps, 1968, p. 679; Kahn, 1978, p. 554; Harcourt, forthcoming, p. 306). According to Keynes (op. cit., p. 303), a condition of "true inflation" would result from the attempt to expand effective demand beyond the point of full employment, defined as an upper 
limit decided by the equality between the real wage and the marginal disutility of employment (ibid, pp. 15-16, 26, 303). The full-employment level of unemployment was described by Keynes (pp. 6, 15) as "voluntary" and "frictional", and presumed to be independent of aggregate demand.

Champernowne and Robinson disputed, on distinct grounds, the assumptions about money-wage behaviour made by Keynes in his discussion of the twin notions of full employment and involuntary unemployment. Champernowne (1936, p. 202) suggested that Keynes's assumption that workers are more sensitive to changes in money-wage rates than to changes in prices only applies in the very short run. As time goes by, workers realize that prices are changing and adjust their money-wage claims accordingly. When there are no unanticipated price changes, the economy will settle at the "basic rate of unemployment" decided by the equilibrium between the curves supply and demand of labour written as functions of real wages only. Champernowne pointed out that real wages will move in the same direction as money-wages only if aggregate demand changes in the process. A crucial element in his analysis, as we shall see below, is the argument that the central bank will eventually change the rate of interest as a reaction to accelerating inflation (and deflation) when the unemployment rate diverges from its basic level, which will turn movements in money-wages into corresponding movements in real wages and bring employment back to its "basic" level.

Robinson (1937a, first essay), on the other hand, rejected Champernowne's "money illusion" premise, as well as Keynes's (1936, p. 14) assumption that workers are basically concerned with relative wage rates. Instead, she put forward the notion of lower and upper "critical levels" of employment at which money-wages respectively fall and rise, according to the bargaining power of trade unions. At employment levels higher than the upper critical level (but still lower than the point of full employment), there will be a progressive rise of wages and prices with a constant level of employment. The rate of inflation will increase if the economy moves to a higher level of activity. This process will be accompanied by falling real wages, as the existence of a contingent of unemployed workers constrain the trade unions from putting in claims for higher 
money-wages to the same extent as the price rise. This changes when the point of full employment is reached, not because there is a critical point at which real wage ceases to cover the marginal disutility of labour as Keynes would have it, but on the grounds that the demand for higher money-wages becomes gradually more successful as employment increases, until all obstacles from the side of labour to a rise in money-wages disappear at the point of full employment. The climax of Robinson's essay on "Full Employment" is the analysis of what prevents the amount of employment decided by the level of effective demand from expanding beyond the limit set by the available supply of labour. She argues (1937a, pp. 15-24) that, if the rate of interest is set below its full-employment level, an ensuing process of accelerating inflation will eventually induce the central bank to bring the rate of interest back to its original level, which has some similarities with Champernowne's argument. Robinson draws the conclusion that full employment is not a feasible goal of economic policy, since it is associated with "acute instability of prices" created by any slight miscalculation in the upward direction. The introduction of imperfect mobility of labour into the picture (which is not touched upon by Champernowne) does not change her main results, as she dismissed Keynes's distinction between the so-called "frictional unemployment" and unemployment caused by low effective demand.

\section{$\underline{\text { Real wages and the level of employment }}$}

David Champernowne's 1936 comparison between the "classical" and the "Keynesian" analysis of unemployment was one of the first attempts to interpret The General Theory using equations and diagrams. As recalled by Champernowne, the paper was based on Keynes's lectures and supervisions in Cambridge from October 1933 to June 1935, and was submitted to the Review of Economic Studies a few months before the publication of Keynes's book (Young, 1987, pp. 82-83; on Keynes's lectures between 1932 and 1935 see Rymes, 1989) ${ }^{1}$. The opening sentences of Champernowne (1936, p. 201) state that the "fundamental

1 See Cowell (1987) for biographical information on Champernowne (born 1912). 
difference" between Keynes's (1936) analysis of employment and the classical formulation of Pigou (1933) is that while the latter assumes that wage bargains between firms and workers determine the real wage rate, the former argues that these bargains can only succeed in determining the money-wage. According to Champernowne (pp. 202 and 204), Keynes put forward two "waves of attack" on the classical system. The first one is the suggestion that the amount of labour supplied is a function not only of the real wage rate, but of the money-wage also, so that "labour's policy with regard to the level of real wages can always be neutralised by changes in the cost of living". The second wave of Keynes's attack is the demonstration that a change in money-wages will not lead to a change in real wage rates in the same direction, unless the rate of interest moves in the same direction as money-wages (cf. Keynes, 1936, pp. 10-12, 265-66, 275). Champernowne finds Keynes's second attack "convincing", but claims that labour's concern with the money-wage rather than the real wage is only a "temporary phenomenon".

The explanation given by Champernowne (p. 202) of money-wage stickiness in the short run is based on the existence of contracts made on the expectation of a stationary cost of living and on the workers's habit of thinking in terms of the price level of the past. An unexpected rise of the price level will, therefore, shift the "real supply curve for labour" rightward at every real wage rate, causing a reduction of real wage rates (since money-wages increase less than the rise of prices) and a higher employment level. An unexpected fall of the price level will have symmetrical short run effects on real wages and employment (cf. p. 215, bottom). But these are temporary effects, since workers will eventually repair their "oversights" of recent changes in the cost of living and will demand a money-wage that ensures them the desired real wage at present prices, which means that the "real supply curve for labour" will shift back to its original position. Champernowne implicitly assumes that the real demand curve for labour is not affected by price changes, since entrepreneurs's expectations of future prices are supposed to be correct (cf. Keynes, op. cit., ch. 5, and note 4 below). The real wage rate that workers would demand if they forecast future prices correctly 
(that is, under Champernowne's assumptions, if the price level had been stationary) is called the "basic real wage", and the corresponding unemployment level is the "basic unemployment" rate (p. 203). Since Champernowne implicitly assumes perfect mobility of labour and the absence of search in the labour market, his "basic unemployment" is the difference between the given labour force and the effective labour supply at the basic level of real wages, that is, voluntary unemployment. $^{2}$

Actual unemployment will be below or above basic unemployment depending on whether the price level is, respectively, rising or falling. Champernowne (p. 204) calls "monetary unemployment" the excess of actual unemployment over basic unemployment, and symmetrically for "monetary employment". He states in a footnote that the concept of monetary unemployment is "copied from Keynes's 'involuntary unemployment', but differs from that concept". The difference, of course, is that while Keynes's (1936, p. 15) concept describes movements off the labour supply curve and situations of excess supply in the labour market, Champernowne has in mind points of (short run) equilibrium of the labour market corresponding to different positions of the labour supply curve. Champernowne might have been inspired by Keynes's definition of involuntary unemployment in terms of price level rise, but, as he realized, the analytical constructions are essentially distinct from each other. ${ }^{3}$ One important difference is that Keynes's (ibid) definition of "full employment" as a fixed upper limit described by the absence of "involuntary unemployment" is quite far from Champernowne's concept of "basic unemployment", for in a situation of "monetary employment" the economy will be above the level given by the basic rate (this is

2 As noticed by Darity and Young (1995, p. 15), Champernowne's basic rate is reminiscent of Milton Friedman's concept of the "natural rate of unemployment". However, Champernowne usually associated his basic rate with a constant and correctly anticipated price level, instead of constant and correctly anticipated rate of inflation as in Friedman. Besides, also in contrast with Friedman, Champernowne did not relate his basic rate to the degree of labour mobility. In any event, job search is mentioned by Friedman but hardly articulated in his framework.

3 "Men are involuntary unemployed if, in the event of a small rise in the price of age-goods relatively to the money-wage, both the aggregate supply of labour willing to work for the 
explained, of course, by rightward shifts of the labour supply caused by unanticipated rising prices). ${ }^{4}$ Furthermore, Champernowne pointed out that the actual rate of unemployment will diverge from the basic rate only temporarily, for workers will tend to repair their "oversights" of recent changes in the price level. The dynamics of this process is an important feature of Champernowne's framework:

A period of monetary unemployment is likely to cause falling moneywages and ... a period of monetary employment is likely to cause rising money-wages. In so far as we can assume that rising and falling money-wages will respectively cause rising and falling real wages, we may conclude that a period of monetary employment contains the seeds of its own destruction in the form of a tendency for real wages to rise, whereas a period of monetary unemployment has in it the seeds of its own destruction, in the shape of a tendency for real wages to fall (1936, p. 204; italics added).

The conditions for real wages to move in the same direction as money wages are discussed in the next section.

Joan Robinson's 1937 Essays "represent an attempt to apply the principles" of The General Theory to a number of problems, as she explains in the foreword dated October 1936. While she later came to change her opinion about the treatment given to some topics (most notably, the chapter on the "LongPeriod Theory of Employment"), the essay on "Full Employment" remained the analytical basis for her discussion of the subject throughout the following decades. The essay was reprinted (together with other essays from the 1937 book, on "Disguised Unemployment" and "Exchange Rates") in volume IV of her Collected Economic Papers (Robinson, 1951-1980, vol. IV, pp. 176-98), preceded

current money-wage and the aggregate demand for it at that wage would be greater than the existing volume of employment" (Keynes, 1936, p. 15; original in italics).

4 It should be noted that Keynes (op. cit., p. 290) mentioned as an aside that entrepreneurs may be deluded by rising prices into increasing employment beyond the profit-maximization level, for they may mistake them for rising relative prices. This adumbration of Lucas's well-known "surprise supply function" can be found in Robertson (1915; see Boianovsky and Presley, 1998), who might had been Keynes's source on that. 
by an "Introduction" where Robinson recalls that Keynes read the draft and that she "cut out anything that I could not persuade him was correct; it can be taken that he accepted my amendment to his definition of full employment" (p. 174). The correspondence between Keynes and Robinson concerning her Essays has since become available as part of volume 14 of Keynes's Collected Writings (Moggridge, 1973, pp. 134-148). ${ }^{5}$ Keynes wrote in a letter of 5 October 1936 that "I like very much indeed the section on full employment and think your treatment is a considerable improvement", and suggested that the book should open with the full employment essay, a suggestion that Robinson followed up. Keynes's increasing concern in the late 1930s and in the 1940s with the prospect of inflation at near-full employment attested to the influence of Robinson in this regard (see Kahn, 1978, pp. 555-57).

The opening section of Robinson's "Full Employment" essay is an attempt to explain why "a fall in real wages, accompanied by an increase of employment, is more universally and strenuously resisted [by trade unions] if it is offered in the form of a cut in money-wages than if it is brought about by a rise in prices", which appears to be "inconsistent" behaviour (1937a, pp. 3-4). She dismisses both Keynes's (1936, pp, 12-14) hypothesis that trade unions are essentially concerned with relative wages instead of the general level of real wages, and Pigou's (1933, pp. 294-96) suggestion that, although trade unions stipulate for a real wage, they only realise after a lapse of time that a rise in prices brings about a decline in real wages. Keynes and Pigou offer interpretations "of trade union psychology" which are both "dubious and unnecessarily complicated". ${ }^{6}$ In this connection, she refers to Champernowne (1936) as consistent with the "Pigovian school". The main flaw of Champernowne's paper, however, is not, according to Robinson, his assumption of money illusion per se, but his failure to distinguish between real wage rates and real earnings. Champernowne's "representative

5 The correspondence between Keynes and Champernowne reproduced in Moggridge (1973, pp. 59-66) deals basically with Champernowne's interpretation of chapter 17 of The General Theory, without any reference to Champernowne (1936). 
worker" (1936, p. 202) should represent both the employed and the unemployed, and, since the real income of unemployed workers will rise as employment increases, the real income of the "representative worker" will rise, not fall, as output increases (Robinson, 1937a, p. 4, n. 2; cf. Keynes, 1936, pp. 13 and 277, for a similar criticism of Pigou). Instead of the explanations put forward by Keynes and the "Pigovian school", Robinson advances the notion that, since trade unions "can only deal in terms of money wages", they demand a rise and resist a cut "whenever they feel strong enough to do so", that is, according to their "bargaining power" decided by the level of employment.

Movements of the level of money-wages result primarily from movements of employment, while the level of employment decides whether the money-wage movement is upwards or downwards:

It is plausible to say, in a general way, that in any given conditions of the labour market there is a certain more or less definite level of employment at which money wages will rise, and a lower level of employment at which money wages fall. Between the two critical levels there will be a neutral range within which wages are constant (1937a, p. 7). ${ }^{7}$

Changes in the price level in itself (that are not a symptom of an increase in employment) affect the money-wage level through their effect on the bargaining power of trade unions. A price rise operates as a shift variable on the supply and demand for labour curves (as function of money-wages), which changes the level of employment and, thereby, the money-wage. From this perspective, the rate of price change is not an additional variable (to the rate of unemployment) in the

6 See also Robinson (1951-1980, vol. V, pp. 201-02) and Robinson and Wilkinson (1985, pp. $93 \mathrm{ff}$ ) for similar critical comments on the classical and Keynes's assumptions, respectively, regarding money-wage dynamics.

7 Solow (1976, pp. 3-4) quotes that passage as evidence of adumbration of the Phillips curve trade off by Robinson. It is worth noting that Robinson herself noticed the similarity with Phillips in her 1973 address on "What Has Become of the Keynesian Revolution?" (Robinson, 1951-1980, vol. V, p. 174) and criticized Phillips for relating changes in money-wages to the level of unemployment, instead of changes in unemployment. However, this is not a fair criticism of Phillips (cf. Phillips, 1958, p. 290). 
determination of changes in nominal wages. As pointed out by Santomero and Seater (1978, pp. 509-10), only anticipated price changes can be validly added to the rate of unemployment to explain money-wage dynamics. Hence, Robinson (pp. 5-6;9) is consistent in her treatment of "movements in the cost of leaving as merely one element in [the trade unions's] bargaining position" (cf. Lipsey's [1960, pp. 8-11] suggestion that a price variable should be added to the original Phillips equation without any mention of price expectation, and the criticism by Santomero and Salter, op. cit.). The impact of expected price changes on labour supply decisions can be found in Champernowne (1936), as we saw above, but was not fully developed.

The influence of a contingent of unemployed workers on money-wage dynamics is an important feature of Robinson's analysis of the labour market (1937a, pp. 6-9). An increase of effective demand is usually accompanied by falling real wages of employed workers as the price level rises, which will affect positively their claims for higher money-wages. On the other hand, previously unemployed workers "would prefer not to open the question of money wages" and to take advantage of the increase in their real earnings. As the level of employment goes up the influence of employed workers on the trade unions's strategy (which are supposed to express the interests of the "representative worker") increases and they gradually demand higher money-wages (as pointed out by King, 1996, p.166, this is reminiscent of the "insider-outsider" theory of the labour market). When employment is constant and above its "critical level", wages and prices will rise continuously at the same rate, but "the existence of unemployed workers anxious to find jobs exercises a drag upon the trade unions and the rise in money wages will be slight and gradual", which explains the apparent "paradox" that increasing employment is accompanied by falling real wages even when trade unions are able to obtain higher money wages.

As Robinson (p. 10) points out, one of the assumptions behind her study of the labour market is the notion that workers do not underbid each other for jobs. The "technology of exchange" (see Howitt, 1988, pp. 150 and 157) is such that job offers are made by firms at a set of "contact points" and workers must sample 
the points to find a job. Although unemployed workers may have some influence inside the trade unions, they do not, outside trade unions, compete directly with employed workers, which means that their chances of getting a job depend on an increase of labour demand by firms, not on offering lower money-wages (cf. Chick, 1983, p. 145). Under these circumstances, unemployed workers are searching for employment and the amount of involuntary unemployment is "the amount of work which, in existing conditions, the population is willing but unable to perform" (Robinson, p. 11). This is not the same as Keynes's definition (quoted in note 3 above), since it identifies the whole amount of unemployment as "involuntary", instead of classifying into different categories (involuntary, voluntary and frictional) as in chapter 2 of The General Theory. Unemployment that is due to wage inflexibility by trade unions is part of "voluntary unemployment" in Keynes (1936, p. 19), while the meaning given by Robinson to "involuntary unemployment" is consistent with the use of the term by other Cambridge economists in the past (see Corry, 1996, p. 19; cf. Robertson, 1915, p. 209). Robinson made it clear in a letter to Keynes in October 1936 that "I tried to get rid of" the idea of voluntary unemployment in the essay on full employment (Moggridge, op. cit., p. 140).

In a perfectly competitive labour market - that is, one with no trade unions and perfect mobility - the two "critical levels" described above coincide at the point of full employment. There would be no trade-off between employment and inflation, since money-wages would be falling all the time if unemployment were positive, and would "rise abruptly" if full employment were reached (Robinson, p. 10; cf. Lipsey, 1978, pp. 59-60). Robinson investigated "frictional unemployment" in detail in her second 1937 essay on "Mobility of Labour", where she critized the view that one can distinguish between unemployment provoked by low effective demand on one side, and caused by "frictions which prevent workers from moving from place to place or from trade to trade in search of employment", on the other (p. 40). That distinction is decisively marred by the fact that the "strength of the frictions" depends on a great extent upon effective demand itself, since the searching time will be lower when effective demand is high (ibid.; cf. 
Howitt, op. cit., and the rest of the "search-externalities" literature developed in the 1980s, which, in contrast with the "reservation-wage" approach of the 1970s, is consistent with involuntary unemployment). The problem of immobility arises when changes in the production pattern, brought about by changes in tastes and techniques, are not, because of the monopsony power of firms in the labour market, accompanied by corresponding changes in relative wages. Under these circumstances, there will be unfilled vacancies in some industries and unemployed workers searching for jobs in others, which is the "only proper sense for frictional unemployment" (letter of 16 October 1936 to Keynes; Moggridge, op. cit., p. 139; see also Robinson, 1937b, pp. 42-43; 1962a, p. 88). The close relation between vacancies and monopsony power pointed out by Robinson has been confirmed in modern models of the labour market (see the survey by Johnson and Layard, 1986, p. 966). A removal of frictions in this case leads to higher employment levels only to the extent that the ensuing reduction of monopsony profits is accompanied by lower savings and, therefore, by a rise in effective demand (Robinson, 1937a, pp. 42-43). The upshot is that the identification of "full employment" with "frictional unemployment" suggested by Keynes (1936, p. 6) is not valid:

It seems preferable to say that full employment, in a precise sense, can never be attained so long as frictions exist, rather than to use "full employment" in an imprecise sense in which it can be said to be attainable, such unemployment as remains being vaguely attributed to frictions (Robinson, 1937a, p. 58). ${ }^{8}$

Keynes reacted positively to Robinson's criticism, but wrote that "I still disagree a little about frictional unemployment". While finding Robinson's treatment of the topic "very helpful and stimulating", he pointed out that "I still consider that

\footnotetext{
Many years later, in her Economic Philosophy, Robinson, under the influence of Karl Popper, changed her mind on the necessity of precision in scientific concepts. She claimed instead that "in the scientific sphere vagueness is more scientific than precision" ([1962a] 1964 , p. 85) and suggested that, in contrast with Keynes's attempted definition, "full employment is bound to be a vague conception". See also Harcourt, 1990, p. 419.
} 
it is a necessary concept to which it is possible to give a useful interpretation" (letter of 5 November 1936; Moggridge, p. 142).

The "precise" description of full employment as frictional unemployment is necessary if it is assumed that unemployment always tends to its fullemployment level, as in the "classical system of analysis". But this is not the case if full employment is regarded merely as the final upper limit to the expansion of employment, for approximations to it are simply a "matter of degree", as she explains on p. 57, n. 2. The view that the difference between trade unions's behaviour below and at full employment is also only a "matter of degree" is behind Robinson's rejection of “Mr. Keynes's psychological interpretation of full employment" (1937a, p. 39, n. 3). She dismissed on two grounds Keynes's definition of full employment as the point at which the falling real wage becomes equal to the marginal disutility of labour on the labour supply curve and workers, therefore, refuse to supply more labour. The first ground, which is discussed in the section after the next one, has to do with Keynes's assumption that the labour supply curve has positive elasticity in relation to the real wage rate, and is not essential (Robinson assumes on p. 12, just to "simplify the argument", that the labour supply has zero elasticity in the relevant range). The second, and crucial, objection to Keynes's definition is that "there is no need to postulate a critical psychological point at which the real wage ceases to cover the disutility of labour". When all the workers in the effective labour force are employed, real wages will stop falling, since "there is no longer anyone whose interest lies in refraining from asking for higher money wages when a further rise in prices takes place" (p. 13; this rules out Champernowne's hypothesis that ex-post real wages may fall, even if real wages anticipated by workers do not). Robinson concedes to Keynes that as effective demand increases and real wages fall, the demand for higher money wages is intensified and the threat of trade unions to withdraw labour becomes more powerful, but

It is merely a matter of degree. The demand for higher money wages is made with growing success as employment increases and when 
full employment is reached it becomes overwhelmingly strong. The point of full employment is the point at which every impediment on the side of labour to a rise in money wages finally gives way (p. 13).

Thus, instead of Keynes's "psychological" interpretation, Robinson puts forward what we may call a "market" interpretation of full employment (assuming away for now imperfect mobility of labour). The consequences of this new definition for economic policy is dealt with in the concluding section.

\section{$\underline{\text { Full Employment and Inflation Acceleration }}$}

Both Champernowne and Robinson endorsed Keynes's view that a change in money-wages, for a given state of effective demand, leads to a corresponding change in prices without any effect on employment and real wages. Champernowne eventually played a key role in convincing Pigou that this was an essential element of Keynes's framework (see the correspondence between Keynes and Pigou of December 1937 reproduced in Moggridge, op. cit., pp. 26566). In the context of his 1936 article, "the demand of labour for a certain real wage can only make itself effective in so far as it influences the attitude of the monetary authority and its manipulation of the rate of interest" (p. 204). ${ }^{9}$ Starting from a position of "monetary employment" - caused, as we saw above, by a temporary inability of workers to realize that prices have gone up - Champernowne argues that workers will demand higher money wages as their "oversight" is gradually repaired, which will lead to a rise in the price level in the same proportion. Workers will react by demanding another rise in money-wages, which will be accompanied by another rise in prices; and so on. According to Champernowne (p. 205), this steady rate of inflation will accelerate, since the "bargaining power" of the representative worker increases as he becomes more confident in his ability to raise his money-wage and, more importantly,

\footnotetext{
9 The criticism by Darity and Young (1995, p. 16) that Champernowne did not realize that money-wage reductions would not affect the real wage is, therefore, unwarranted.
} 
The speed with which he will revise his demands in the face of increases in the cost of living will become greater the more accustomed he becomes to the danger of his real wage being reduced by the rise in the cost of living. We see that a period of monetary employment will be accompanied not merely by rising money-wages and prices, but moreover by money-wages and prices rising at a rapidly increasing rate (p. 205; italics added).

This is, of course, reminiscent of the famous accelerationist result of the "natural rate of unemployment hypothesis" formulated by Milton Friedman (1968) and Edmund Phelps (1968). The only way to keep the rate of unemployment below its equilibrium or "basic" level is by increasing the rate of inflation. As in Friedman and Phelps, the mechanism behind acceleration is the (not fully developed) assumption that workers form their expectation of price increase based on past rise in prices, that is, adaptative expectations. Furthermore, Champernowne suggests in the passage quoted above that the length of wage contracts is reduced as workers become more aware of the price increase process, which contributes to the acceleration of the inflation rate.

The acceleration process will eventually and indirectly bring about an increase in real wages, since the monetary authority "would be forced to put a stop to it" (p. 205) by means of a higher rate of interest. However, since the action of the central bank is not anticipated, there would probably be an overshoot, with real wages rising "sharply" and the amount of employment falling below the level corresponding to "basic unemployment". The argument for the case of "monetary unemployment" is similar: the process of falling money-wages and falling prices "is likely to become accelerated as labour becomes more disorganised by the depression, and as employers get more desperate and more confident in their power to cut money-wages" until eventually "the lunacy of the situation will be realised" and the monetary authority puts an end to the deflationary process, which leads to a reduction of the real-wage rate. Interestingly enough, in contrast with the inflationary process, the acceleration of price fall is not explained by defla- 
tionary expectations of workers, but by the effects of a persistently low level of employment on their bargaining power.

The upshot is that periods of monetary employment or of monetary unemployment are not likely "to last for very long", so that actual unemployment oscillates around the level of basic unemployment, which corresponds to the "trend value" of unemployment. Based on that, Champernowne (p. 206) suggests that the "ordinary tools of classical analysis" should be used when trend variables are the object of investigation and the assumption can be made that the amount of unemployment is not affected by the price level (pp. 206-9). The main tool of classical analysis is the "real supply curve of labour", which may be a useful concept to estimate the trend of unemployment and of the interest rate, "provided that the monetary authority does not allow labour to be misled by too long periods of rising or falling cost of living" (p. 216). Classical analysis will not do, however, if the rate of interest - because of scarce investment opportunities or money hoarding caused by fragile expectations of entrepreneurs - cannot be reduced sufficiently to avoid falling prices and monetary unemployment.

Inflation acceleration is also conspicuous in Robinson's investigation of the working of the economy under conditions of excess demand for labour, or "scarcity of labour" (1937a, p. 14). "At first sight it appears that there is nothing to prevent" effective demand from being so high that "the appropriate amount of employment lies beyond the limit set by the available supply of labour". Under these circumstances, "something must occur to prevent employment from expanding any further, but it is not immediately obvious how this comes about" (ibid, p. 15; cf. 1952, p. 129, where she pointed out that "it is by no means obvious through what mechanism full employment can bring a boom to an end"). A similar problem was discussed by Keynes (op. cit., p. 289), and his solution based on the definition of full employment criticized by Robinson - is that prices and money-wages rise in the same proportion, given the equality between (the now constant) real wage and the marginal disutility of labour. This process of "true inflation" increases the transactions demand for money, which leads to a higher rate of interest and prevents expenditure from overshooting the point of 
full employment. Keynes concludes that the rate of interest "cannot be in equilibrium at a level below the rate which corresponds to full employment" (p. 202; italics in the original). As noticed by Hawtrey $(1937$, p. 455) in his review of the Essays, Robinson followed Keynes up in her search for the mechanism that would bring the rate of interest back, but she found it in the acceleration of inflation, instead of a given rate of inflation as in Keynes. ${ }^{10}$

Robinson's treatment of the effects of a reduction of the rate of interest in full employment is reminiscent of the well-known "cumulative process" of Knut Wicksell ([1898] 1936), which had just been translated by Richard Kahn. She did not refer to Wicksell, but mentioned Hayek (1935), who, of course, referred to Wicksell extensively. A reduction in the rate of interest raises the price of capital goods and increases demand for labour in the capital-goods industries, which immediately leads to a rise in money-wages in those industries (as full employment prevails). The rise in money-wages is communicated to the consumptiongoods industries through expenditures from workers employed in the capitalgoods sector. The dynamics of the process depend, first, on whether changes in wages are instantaneous (if they are, no increase in real investment measured in wage units can take place, since there is no actual transfer of labour between the two sectors), and, second, upon how entrepreneurs's expectations are influenced by changes in wages (Robinson, 1937a, p. 18).

She starts by assuming that changes in wages are instantaneous, and argues that a rise in money-wages reduces only temporarily the incentive to invest, since the prices of the commodities which will be produced with capital goods

10 The problem is different in connection with the limit set by capital equipment capacity, as Robinson (p. 15) pointed out. In this case, real wages will fall and profits will increase as output expands, which will bring about an increase in the ratio of saving to consumption under the usual assumptions about the savings from profits and from wages. In the limit, when the output of consumption goods reaches full capacity, prices and profits will rise to the extent necessary to prevent consumption from increasing. This check - through a fall in real wages - upon the expansion of effective demand does not operate if the limit is set by labour. Furthermore, as explained by Robinson (p, 176), it is formally impossible for the point of full capacity in consumption goods to be reached before the point of full employment, which is, therefore, the upper limit to the possible expansion of output. Kaldor (1938, p. 644, n. 1) referred to Robinson's definitions, but blurred the distinction by suggesting that in both cases the limit is set by increasing money -wages. 
have risen in the same proportion as money-wages. If entrepreneurs adjust their expectations of the future rate of return of capital-goods instantaneously to changes in money-wages, the marginal efficiency of capital cannot be reduced even temporarily to equality with the rate of interest, and "no equilibrium is possible". If, however, entrepreneurs react more quickly to the rise in money-wages than to the change in prospective earnings (a more "natural" hypothesis according to Robinson), the marginal efficiency of capital will be temporarily reduced, which means that there is a certain rate of rise in money-wages that preserves equality between the marginal efficiency of capital and the lower rate of interest.

Thus the rate at which money-wages rise will necessarily be whatever is required to maintain equality between the marginal efficiency of capital and the rate of interest. The more rapidly are the expectations of entrepreneurs revised the more rapid will be the rise in money wages. Expectations will be revised more rapidly as experience teaches the entrepreneurs that a rise in costs in their own industries is accompanied by a rise in prices in others. Thus the rate of rise in money wages will accelerate as time goes by. In the limit, as we have seen, if expectations are revised instantaneously money wages must rise indefinitely fast (p. 20; italics added).

If entrepreneurs expect money-wages to rise again in the future, the acceleration process will be further intensified (cf. pp. 20-21).

Robinson next relaxes the assumption that changes in money-wages are instantaneously communicated between industries, and postulates instead that wage contracts apply to given periods of time. The difference from the previous case is that a reduction of the rate of interest will this time bring about an increase of real investment and a fall in the supply of consumption-goods, since workers will move from the consumption-goods sector attracted by higher wages in the capital-goods industries. The ensuing increase in the price level of consumption-goods will raise their profitability and lead entrepreneurs in that sector to offer higher money-wages to attract workers back. This will provoke a reac- 
tion from the capital-goods sector, and so on, in a "perpetual tug-of-war between the two groups" with an upward and accelerating movement of prices and wages. Robinson (p. 22, n. 1) notices that "this analysis bears a superficial resemblance to that of Professor Hayek" in lecture III of Prices and Production. In another essay in the book, Robinson (p. 248) mentions Hayek's (1935, pp. 149-51) argument that "an accelerating rate of increase in the amount of money is necessary to prevent collapse" of the forced saving process. Despite this, she points out in the same footnote that there is no "genuine point of contact between [Hayek's] argument and the above", since Hayek (1935) assumes full employment in his interpretation of the business cycle. In any event, Hayek's accelerationist result is not based on entrepreneurs's expectations formation as is Robinson's, but on the view that the new capital-intensive processes of production can only be completed if the supply of credit expands at an increasing rate (see Laidler, 1999, pp. 42-46, for a critical comment on Hayek's accelerationism).

Inflation acceleration under full employment conditions can also be found in Wicksell (1936, pp. 96-97) and Lindahl (1939, p. 182), but it is explained by the hypothesis that, after the inflationary process has started, entrepreneurs begin to anticipate higher prices in the future (that is, have adaptative price expectations). Robinson (p. 23) considers this possibility merely as another contributing factor to the acceleration process, not as a decisive element. "After prices have been rising for a certain time an expectation is likely to be set up that they will rise further in the future", which will stimulate the demand for investment and consumption because of the fall in the "real" [Fisherian] rate of interest (pp. 2324). The main factor behind acceleration in Robinson is the progressive reduction in the time lag assumed in the effects of higher prices of consumption-goods on rising capital values, a lag that is assumed to be constant by the Wicksellians (cf. Lindahl, op. cit., pp. 172-73).

Robinson assumes, throughout the above discussion of inflation acceleration, perfect mobility and absence of monopsony in the labour market in order to simplify the argument, but maintains that "the main conclusion" that scarcity of 
labour leads to a "rapid and accelerating rise in money wages" would hold good if more realistic assumptions were made about the labour market.

The general upshot of our argument is that the point of full employment, so far from being an equilibrium resting place, appears to be a precipice over which, once it has reached the edge, the value of money must plunge into a bottomless abyss (p. 24).

The analysis so far has been based on the assumption of a perfectly elastic money supply, which Robinson now qualifies. She suggests that, in order to prevent a process of inflation acceleration, monetary authorities will react by raising the rate of interest and checking a rise in money-wages "long before the point of full employment is actually reached" (p. 26; she also mentions the repercussions for the exchange rate in the case of an open-economy). The belief that accelerating inflation is not normally a feature of the economic system and that the "fear of inflation" checks boom conditions can be also found in her introductory volume (1937b, p. 96). As we saw above, this is not far from Champernowne's view. However, Robinson considered the possibility that a different monetary and fiscal regime (as we would say now) might prevent the operation of the "safeguards", which she illustrated on pp. 28-29 with the case of a country beset with a persistent budget deficit financed by borrowing from the central bank.

\section{$\underline{\text { Diagrammatic Representation }}$}

Champernowne and Robinson used diagrams to illustrate their concepts, but they both restricted diagrammatic analysis to the discussion of comparative statics, without any attempt to incorporate a diagrammatic representation of dynamic processes involving endogenous changes in expectations. Nevertheless, diagrams are especially useful to illustrate Champernowne's suggestion (p. 212) that the key difference between Keynes and the classics is that the former postulates that the supply of labour is also influenced by the money-wage rate, not just by the real wage (see also Darity and Young, 1995, pp. 15-19, for a discussion of 
Champernowne's equations and diagrams, and a comparison to the Hicksian ISLM formulation). Another important difference between the classical and the Keynesian systems is, according to Champernowne (pp. 211-12), the impact of "general nervousness, the state of the news" and price level expectations on the demand for money and for investment in The General Theory. The determination of the endogenous variables - that is, employment $N$, real wage $R$, saving $S$, market rate of interest $r$, money stock $M$ and money-wage $w$ - is different in the two systems; see figures 1 and 2 below. In the classical scheme the starting point is the labour market with supply and demand curves in real terms, while the Keynesian scheme starts with the determination of the rate of interest, which decides the position of the "demand for saving" curve in diagram $e$. Given the employment level and the corresponding real wage, "labour's demand" curve in diagram $f$ determines the money-wage together with the vertical "employers's offer" curve (Champernowne's curve is not strictly vertical, but it must be; cf. Darity and Young, op. cit., pp. 18-19). The slope of "labour's demand" curve reflects the degree of money illusion of workers; it would be vertical if labour supply depended only on real wages (see Champernowne, p. 215).

Champernowne (pp. 213-14) illustrated the difference between the classical and Keynesian systems by examining the consequences on the endogenous variables of an increase in thriftiness (that is, a rightward shift in the supply curve of saving). The diagrams in the classical system indicate that savings will increase, the rate of interest, the money-wage and the price level will fall, and the amount of money, the real wage and the employment level (corresponding to the basic rate of unemployment) will not change. Applying the Keynesian technique to the problem, the rate of interest will not change, and employment and saving will fall. These will cause, in the Keynesian labour market, a rightward shift of the demand curve for labour and a leftward shift of the supply curve (for "the fall in employment will have made labour more prepared to accept a cut in moneywages"), so that the real wage will go up, the price level will fall and the moneywage will fall in a lesser proportion. The "indirect" effects will be a leftward shift of the demand curve for money because of the reduction in prices and employ- 
ment, and a leftward shift in demand for savings curve if an expectation of falling prices affects investment negatively.

Champernowne did not use his diagrammatic representation of the Keynesian system to show how the economy, starting from a position of "monetary unemployment", would gradually move towards the basic unemployment rate. Applying Champernowne's (p. 205) discussion of monetary unemployment to figure 2 , it can be easily seen that the ensuing process of falling money-wages (caused by the workers's realization that prices have gone down in the recent past) and prices at the same proportion will shift the supply curve in diagram $f$ successively downward at constant real wages, which will eventually lead to an acceleration of deflation and a reduction of the rate of interest by the central bank (a rightward shift of the money supply curve in diagram $d$ ). A symmetrical analysis could be applied to the case of "monetary employment", but this would be quite foreign to Keynes's framework. It is worth noting that the imputation of labour's money illusion to the classical system implies that the real supply curve in diagram $a$ shifts to the right when the price level is rising and to the left when prices fall. However, as Champernowne (pp. 211 and 215) notices, the classical economists did not clearly incorporate that as part of their framework, let alone the shift back of the curves when workers repair their "oversights". When the economy is trapped in a persistent condition of monetary unemployment caused by "nervousness" of employers, the classical analysis cannot be readily used, according to Champernowne (p. 216), because it can only treat this situation as an indirect effect of falling prices on the position of the real labour supply curve, instead of the direct effects of "nervousness" that are part of the Keynesian approach. 


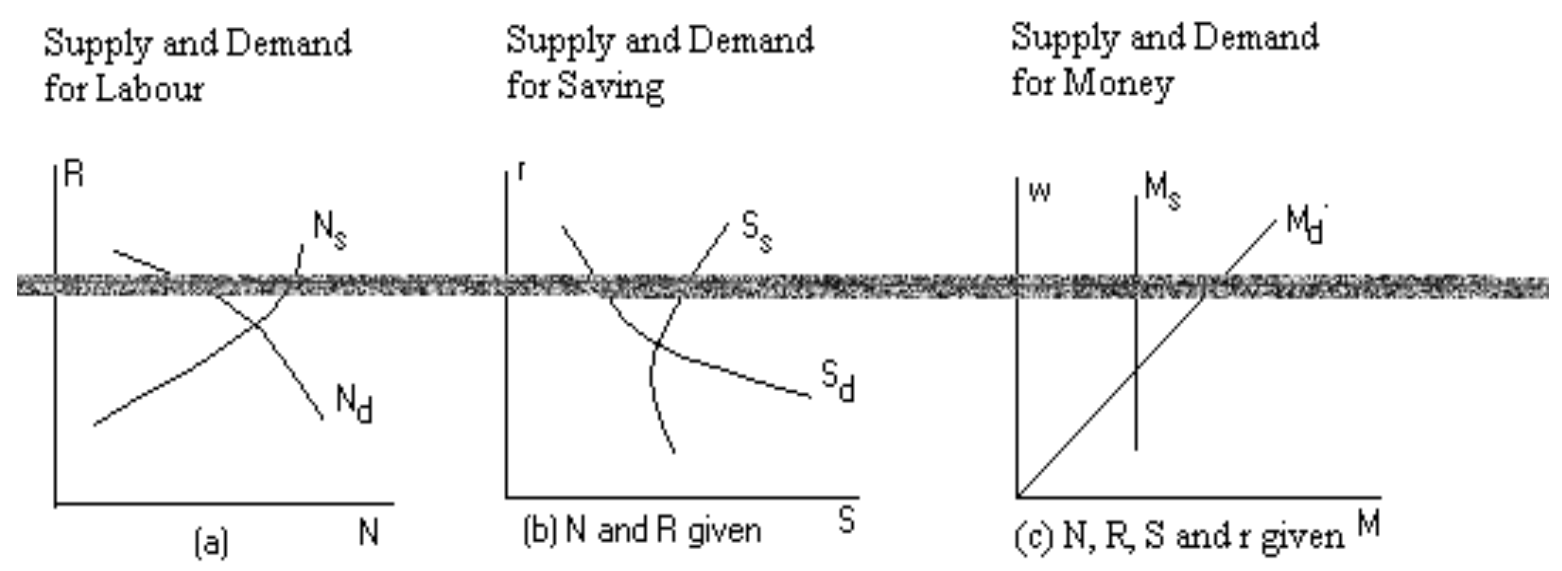

Figure 1. Classical Scheme (Source: Champernowne, 1936, p.212)
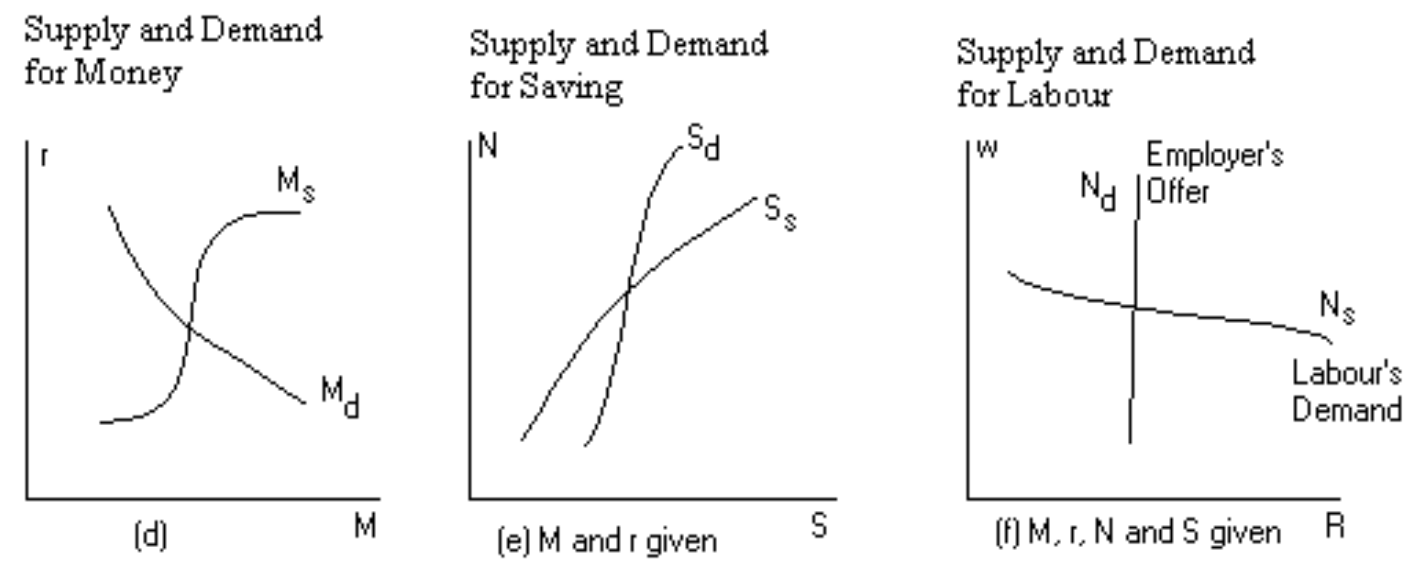

Figure 2. Keynesian Scheme (Source: Champernowne, 1936, p.213)

Robinson (1937a, pp. 162-180) devoted one of her essays in the book to the "diagrammatic illustrations" of her previous essays on "Full Employment" (pp. 339) and "The Long-Period Theory of Employment" (pp. 105-38), which is, according to Robinson, the relevant period to study the equilibrium employment level (instead of Keynes's short period). The diagrams are not, in contrast with Champernowne, a comparison between the classics and Keynes, but just an attempt to give a diagrammatic treatment of "the General Theory of Employment" despite the intrinsic difficulty in reducing its concepts to "precise quantitative terms" (1937a, p. 162). Robinson's diagrammatic representation is based on two curves, namely the long-period demand curve for labour and the supply curve of labour. While the supply curve describes "the amount of labour which a given 
population is able and willing to provide" according with the ruling level of real wages (pp. 162-63), the demand curve relates the level of employment to the corresponding real wage. It is not a usual demand curve, since both real wage and employment are dependent upon changes in the rate of interest (pp. 168-69). The long-period level of employment corresponds to the output level at which saving and investment are zero, describing a situation where the stock of capital is constant and adjusted to the given rate of interest (pp. 106-09). Robinson (pp. 11119; see also Kregel, 1983) shows that the equilibrium (long-period) levels of output and employment may be either increased or reduced by a fall in the rate of interest, according to whether direct effect of the lower rate of interest on saving out of a given income is negative or positive, and depending on whether the elasticity of substitution between labour and capital is below or above unity (which decides the effect of the rate of the rate of interest on distribution). Moreover, assuming away land and natural resources, a fall in the rate of interest always raises the real wage rate, which means that the elasticity of the long-period demand curve may be either positive or negative (p. 169).

Robinson's supply curve of labour is built upon Dennis Robertson's (1931, p. 7) suggestion that the supply of labour of a given population is determined by "time worked" (divided into "working life" and "working year") and "efficiency". The result is a curve that incorporates the effects of changes in real wages on the participation rate, hours of work and efficiency of workers, in contrast with the positively sloped labour supply curve of both Keynes (in chapter 2 of The General Theory) and Champernowne. ${ }^{11}$ She postulated a labour supply curve which is forward rising at low real wages, reaches a point of zero elasticity and then becomes backward rising at higher real wages, under the assumption that the amount of work provided by a representative family of given efficiency falls as the real wage rises (see Robinson, pp. 10-11 and 165; 1962a, pp. 86-87;

11 As Robertson (1963, pp. 306-07) pointed out, Keynes applied in his chapter 2 the concept of a rising supply curve to the numbers of a given adult male population seeking work and attributed it to Pigou (1933). However, as Robertson explained, Pigou's labour supply curve in this case is formed by a vertical straight line and a horizontal segment at a minimum real wage. 
she mentioned in 1937 evidence provided by Paul Douglas's Theory of Wages, the same source of Jacob Viner's 1936 criticism of Keynes in this regard). The marginal improvement in efficiency due to higher real wages is diminishing, until it eventually ceases to compensate for the reduction in time worked as real wages rise, which explains the shape of the $S$ curve in figure 3 below (real wages per unit of work is measured on the $y$ axis and units of work on the $x$ axis). It should be noted, furthermore, that Robinson assumes a high degree of labour mobility in order to render the concept of aggregate supply of labour "precise" (1937a, p. 163).

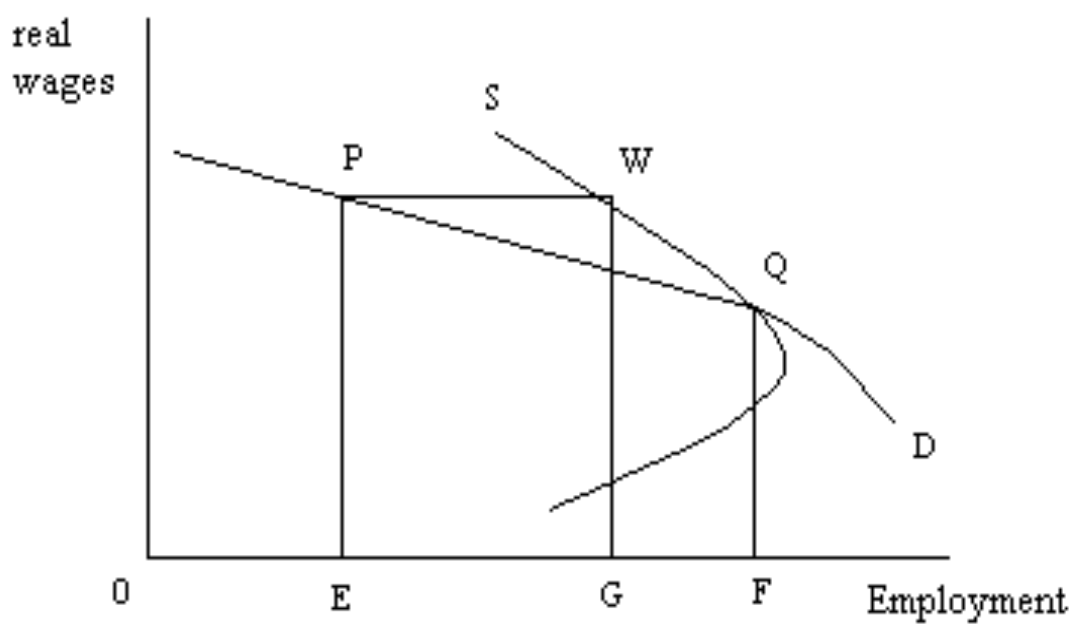

Figure 3. Labour Supply and Demand Curves (Sources: Robinson, 1937a, p. 177)

Figure 3, drawn under the assumption that a fall in the rate of interest always increases the long-period level of employment along the $D$ curve, illustrates an economy with an actual level of employment $O E$ (determined by the level of the rate of interest and the corresponding point $P$ on the demand curve) and an amount of unemployment $E G$, that is, the amount of labour searching but not finding employment at the ruling real wage rate. The point of full employment is $Q$, defined by the intersection of the supply and the demand curves. Robinson (p. 173) is at pains to make clear that the point of intersection $Q$ "is not of the same nature as the point of intersection of ordinary supply and demand curves", 
for "it does not represent a point of equilibrium, but merely the point beyond which it is impossible for employment to expand". Figure 4 consists of four different cases of elasticities of the demand and supply curves at the point of intersection. Robinson (p. 172) rules out the possibility of an unstable equilibrium, which would happen if, at the intersection point, the demand curve were so inelastic that a backward rising supply curve would cut it from above (cf. Robertson, 1963, p. 310). Keynes's definition of involuntary unemployment is consistent with the level of employment $O F$ in figure $4 \mathrm{~d}$ at which there is no involuntary unemployment. Thus, as Robinson (p. 172, n. 1) pointed out, Keynes's definition is valid only under short period conditions (for only then is a fall in real wages a signal of an expansion in effective demand) and under the assumption that the elasticity of the labour supply curve is not negative.
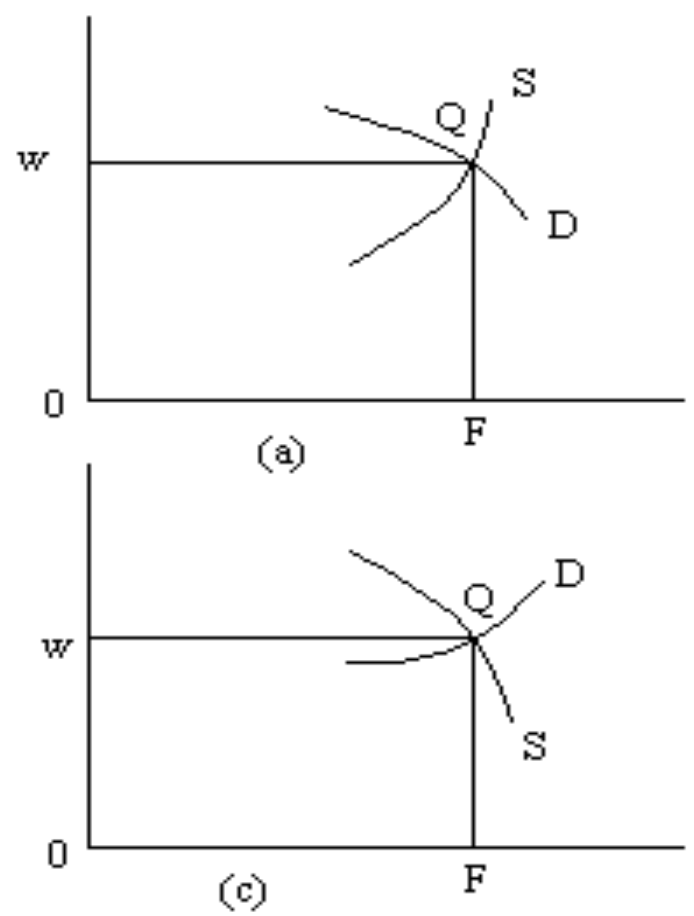
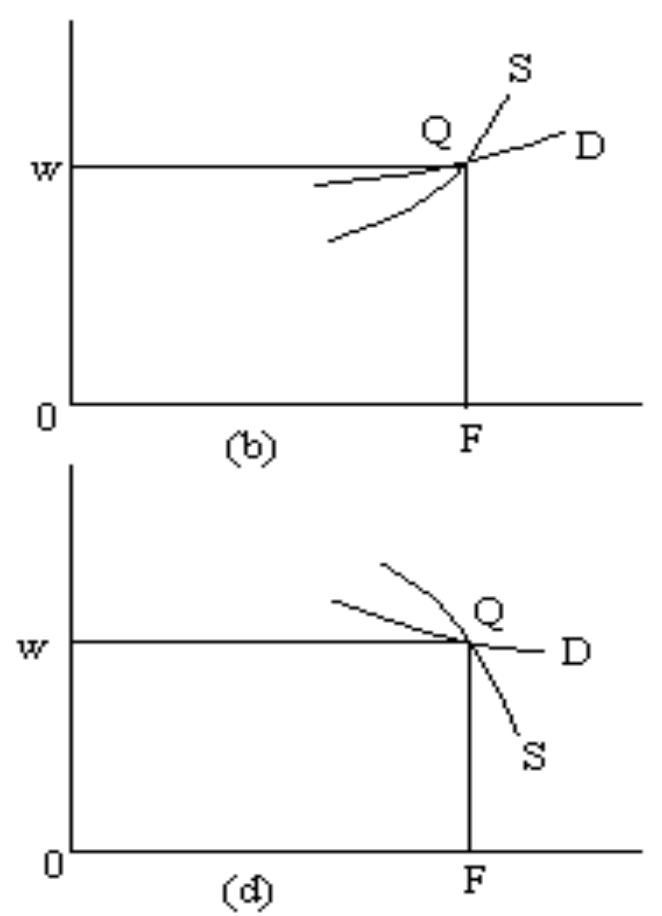

Figure 4. Points of Full Employment (Source: Robinson, 1937a, p. 171)

Robinson did not use the diagrams to illustrate the notion of a "critical" employment level at which money-wages start to rise or fall, developed in her "Full Employment" essay. The reason, of course, is that only real wages are depicted in her diagrams. Neither did she use diagrams to represent the process of inflation acceleration when the level of employment decided by the $D$ curve lies 
beyond the limit set by the labour supply curve. In the case of a "poor community", the level of income corresponding to full employment may produce negative saving. The long-period equilibrium level of employment (with zero savings) would exceed labour supply. "The solution to this problem", according to Robinson (p. 109, n. 2), "lies in the fact that the rate of interest cannot be maintained at a value at which the demand for labour overruns the limit set by the available supply, for the attempt to maintain it would lead to cumulative inflation", and she refers to her discussion in the "Full Employment" essay. In this way, the reaction function of the central bank under potentially inflationary conditions is invoked to explain why a rate of interest "persistently" (as it is appropriated for long-period analysis; cf. p. 105) below its full employment level is an impossibility, and at the same time, to assume away any points beyond the intersection between the labour demand and supply curves.

\section{Concluding Comments}

After their initial reaction to Keynes's employment theory in the 1930s, Champernowne and (more extensively) Robinson returned to the topic in the 1950s and 1960s, but without any further discussion of accelerating price movements around full employment. In the 1970s, Robinson $(1974,1979)$ came to realize, under the impact of the stagflation process that had been set off, that accelerating inflation could emerge whenever employment is above its critical level. During the 1950s and the 1960s, Champernowne and Robinson (and many others) became attracted to the study of economic growth and problems associated with the measurement of capital in the process of capital accumulation. It was in that context that Champernowne (1958, p. 211) examined the mechanism by which, under the assumption of full employment, savings may be used to increase productivity in order to allow employment to remain full. The "monetary effects" arising from the fixing of contracts and wages in terms of money rather than in terms of consumption goods - that had been discussed in his 1936 piece - were explicitly assumed away, together with "major errors of foresight". Champer- 
nowne (1958, pp. 224-26) did consider that capital accumulation at full employment could be interrupted by an "inflation crisis", but this time it was based on the notion that workers demand increasing money-wages if the rate of growth of real wages ever falls below some prescribed level.

The reprint of his 1936 article in the well-known Lekachman volume of 1964 was accompanied by another paper by Champernowne on Keynesian economics. In Champernowne's (1964, p. 174) opinion, the main difference between Keynes and the classics is the former's emphasis on expectations and the links between the economic future and the present, not the treatment of the labour market (an opinion that would be increasingly shared by Robinson in the 1960s and 1970s, as is well-known). Expectations, of course, play an important role in shifting the curves in the 1936 article (see Champernowne's testimony in Young, 1987, pp. 85-86), but in 1964 Champernowne introduced producers's expectations from the start in the determination of the equilibrium position. Interestingly enough, as far as money wage stickiness is concerned, Champernowne (1964, pp. 197-98) remained unconvinced by Keynes's (1936, p. 238) argument that wages are necessarily more sticky in terms of the commodity with lowest elasticity of production and with lowest excess of carrying-costs over liquidity-premium, that is, in terms of money. Champernowne's life-time interest in probability and uncertainty led him to the study of Bayesian analysis and culminated in his Uncertainty and Estimation in Economics, which contains a brief discussion of Keynes (Champernowne, 1969, vol. 3, pp. 79-84).

Robinson's 1937 notion of inflation acceleration at full employment surfaced again in the concept of the "inflation barrier" to capital accumulation, defined as a limit to the level to which real wages can fall without setting up a pressure to rise money-wages (1956, pp. 48-49). Normally, the inflation barrier operates only in conditions of full employment, since the bargaining power of workers is not strong enough to check a fall in real wages at a lower level of employment. As in her 1937 essay, Robinson (1956, pp. 238-39) points out that the inflation barrier operates through the increase in interest rates set off by the central bank's “fear of inflation” (see also Robinson, 1962b, pp. 72-73). Robinson's explanation 
of the upper turning point is not, however, based on the operation of the inflation barrier, since "another barrier lies in front of it, set by the capacity of plant in the industries specialised in the production of plant" (1956, p. 200; cf. 1952, pp. 129 36). This was not part of her 1937 framework, for the 1950s notion of longperiod equilibrium in the domain of economic growth theory was unheard of before the Harrodian revolution.

Champernowne's and Robinson's respective interpretations of labour market dynamics in the 1930s have clear implications for the formulation of economic policy. Although Champernowne (1936) did not explore this, one of the corollaries of his analysis is that a rate of unemployment below the "basic rate" is not a feasible goal of economic policy because it is associated with accelerating inflation. Robinson (1937a, pp. 29-39; cf. King, 1996, p.178) extensively discussed the policy implications of her reformulation of Keynes's concept of full employment. After dismissing full employment as the object of macroeconomic policy - on the grounds that "a slight miscalculation in the forward direction" will lead to "a rapid and accelerating rise in money wages" (p. 30) - she examines four possible goals, namely high (but below full level) of employment, stability of the exchanges, stability of the price level, and maximization of the real income of wage earners. Robinson found the second and third criteria for economic policy wanting, since they could lead to relatively low employment levels. The first criterion would probably entail that employment lies above the "upper critical level" (given the bargaining power of trade unions), which means that a policy of high employment would be accompanied by a constant rise in the price level (pp. 8 and 31; cf. Phelps's [1968, p. 679] reference to Robinson). The last criterion is such that, for a given money supply, the monetary authority allows employment to be decided by the trade unions's objective of maximizing the real income of the" representative worker" (which combines employed and unemployed workers). The "optimum employment" level (p. 38) is such that, at the corresponding real wage of employed workers, aggregate real income of workers is maximized (cf. Johnson and Layard, 1986, pp. 973-74, for a similar model of trade union behaviour). The two critical levels of employment would, therefore, coincide at 
the optimum employment level, which would have the characteristics of full employment. Robinson (p. 39), however, was skeptical of the possibility of trade unions acting in concert with each other, since they are primarily interested in the welfare of their own members.

The trade-off view implicit in the notion that rising prices are the cost to be paid by a high employment level became part and parcel of Robinson's discussion of economic policy. In her 1962 review of a book by Harry Johnson, Robinson stated that "as far as inflation is concerned, Keynes's theory led to the prediction that a high level of employment would be liable to lead to rising prices" (Robinson, 1951-1980, vol. II, p. 101; italics in the original; see also vol. II, p. 107; vol. V, pp. 96-97, 174 and 201, where she referred to the Phillips curve). The solution proposed by Robinson (1966, pp. 12 ff; 1971, p. 93; 1974) to escape from the dilemma posed by the trade-off between inflation and unemployment was, as is well-known, the adoption of "incomes policy", which had not been mentioned in her 1937 menu of policies. However, in the 1970s, Robinson started to doubt the existence of a stable trade-off and applied to "high employment" the accelerationist argument she had discussed before in connection with full employment. Despite realizing already in 1937 (p. 31) that a policy of high employment accompanied by rising prices was bound to "set up an expectation of rising prices in the future", Robinson implicitly denied that the inflation rate could accelerate below the point of full employment. Apparently, this was based on her implicit assumption that acceleration would emerge only if real wages were not falling, as at the point of full employment. Later on, she explicitly stated that, despite inflationary expectations, relatively constant and mild rate of inflation could go on forever without accelerating, which reflected the economic history of the developed countries during the so-called "age of growth" after World War II (1966, p. 7; 1971, p. 93). It was apparently not the publication of Friedman (1968) and Phelps (1968), or even a belated influence of Champernowne (1936), that made Robinson change her view, but the impact of the stagflation episode of the 1970s. 
It is an obvious corollary from the Keynesian theory of prices that a successful policy of of maintaining near-full employment without any other change in the industrial system entails money-wage rates rising faster than output per head and therefore a chronic tendency to rising prices. A sudden speeding up of inflation, such as we are suffering now, can be attributed to particular events, but these are not the b asic cause; if mildly rising prices continue, year after year, there is bound to be some historical accident, sooner or later, that will impinge upon the process and speed it up. Moreover, even without any external shock, mild inflation has an inherent tendency to speed itself up, because an expectation of rising prices causes price to rise (1974, p. 488; italics added).

Robinson did not spell out on that occasion the mechanism that leads to inflation acceleration, but in 1979 (p. 13) she suggested that "continued inflation even at 3 per cent per annum tends to accelerate as more and more bargains are made in the light of expectations of higher prices in the immediate and farther future, and this makes the system accident-prone". The "bargains" would presumably include not just money-wage bargains (cf. Robinson, 1951-1980, vol. V, p. 202), but also the markets for goods and assets (cf. Robinson and Eatwell, 1973, pp. 213 and 307). Robinson's criticism of the natural rate of unemployment hypothesis (see Robinson, 1951-1980, vol. V, pp. 201-02) could probably also be applied to Champernowne's "basic unemployment rate", but the notion that (in the absence of a successful incomes policy) high employment is not a feasible goal of economic policy, together with the notion that price and wage flexibility will not make the economy converge automatically to its full employment level, brings her closer to the 1936 and 1964 views of her Cambrid ge colleague. 


\section{$\underline{\text { References }}$}

Boianovsky, M. and J. R. Presley. 1998. Dennis Robertson and the Natural Rate of Unemployment Hypothesis. Economic Research Paper 98/11. Loughborough University.

Champernowne, D. G. 1936. Unemployment, Basic and Monetary: The Classical Analysis and the Keynesian. Review of Economic Studies. 3: 201-16.

Champernowne, D. G. 1958. Capital Accumulation and the Maintenance of Full Employment. Economic Journal. 68 (March): 211-44.

Champernowne, D. G. 1964. Expectations and the Links Between the Economic Future and the Present. In K. Lekachman (ed.): Keynes's General Theory: Report of Three Decades. New York: St. Martin.

Champernowne, D. G. 1969. Uncertainty and Estimation in Economics. San Francisco: Holden Day.

Chick, V. 1983. Macroeconomics After Keynes. Cambridge (Mass.): MIT Press.

Corry, B. 1996. Unemployment in the History of Economic Thought: An Overview and Some Reflections. In B. Corry (ed): Unemployment and the Economists. Cheltenham: E. Elgar.

Cowell, F. A. 1987. Champernowne, David Gawen (born 1912). In J. Eatwell et al (eds): The New Palgrave: A Dictionary of Economics, vol. 1, p. 401. London: Macmillan.

Darity, W. and W. Young. 1995. IS-LM: An Inquest. History of Political Economy. 27.1: 1-41.

Friedman, M. 1968. The Role of Monetary Policy. American Economic Review. 58 (March): 1-19. 
Harcourt, G. C. 1990. Joan Robinson's Early Views on Method. History of Political Economy. 22.3: 411-27.

Harcourt, G. C. forthcoming. A Left Keynesian View of the Phillips Curve. In R. Leeson (ed): A. W. H. Phillips Collected Works in Contemporary Perspective. Cambridge:Cambridge University Press.

Hawtrey, R. G. 1937. "Essays in the Theory of Employment". Economica. 4 (Nov): 455-60.

Hayek, F. 1935. Prices and Production. 2nd. edn. London: Routledge.

Howitt, P. 1988. Business Cycles with Costly Search and Recruiting. Quarterly Journal of Economics. 103.1: 147-65.

Johnson, G. E. and P. Layard. 1986. The Natural Rate of Unemployment: Explanation and Policy. In O. Ashenfelter and R. Layard (eds): Handbook of Labour Economics, vol. II, ch. 16. Amsterdam: Noth-Holland.

Kahn, R. 1978. Some Aspects of the Development of Keynes's Thought. Journal of Economic Literature. 16.2: 545-558.

Kaldor, N. 1938. Stability and Full Employment. Economic Journal. 48 (Dec): 642-57.

Keynes, J. M. 1936. The General Theory of Employment, Interest and Money. London: Macmillan.

Keynes, J. M. [1937] 1973. The General Theory of Employment. As reproduced in D. Moggridge (ed), pp. 109-23.

King, J. E. 1996. The first post Keynesian: Joan Robinson's Essays in the Theory of Employment (1937). In P. Arestis and M. Sawyer (eds). Employment, Economic Growth and the Tyrany of the Market: Essays in Honour of Paul Davidson, ch. 10. Aldershot: Elgar. 
Kregel, J. A. 1983. The Microfoundations of the "Generalisation of The General Theory " and "Bastard Keynesianism": Keynes's Theory of Employment in the Long and Short Period. Cambridge Journal of Economics. 7 (Sept/Dec): 343-61.

Laidler, D. 1999. Fabricating the Keynesian Revolution. Cambridge: Cambridge University Press.

Lindahl, E. 1939. Studies in the Theory of Money and Capital. London: Allen and Unwin.

Lipsey, R. G. 1960. The Relation Between Unemployment and the Rate of Change of Money Wage Rates in the United Kingdom, 1862-1957: A Further Analysis. Economica. 27.1: 1-31.

Lipsey, R. G. 1978. The Place of the Phillips Curve in Macroeconomic Models. In A. R. Bergstrom et al (eds): Stability and Inflation - A Volume of Essays in Honour of the Memory of A. W. Phillips. New York: J. Wiley.

Moggridge, D. (ed.) 1973. The Collected Writings of John Maynard Keynes. Vol. 14. London and Cambridge: Macmillan and Cambridge University Press.

Phelps, E. S. 1968. Money-Wage Dynamics and Labour-Market Equilibrium. Journal of Political Economy. 76.4: 678-711.

Pigou, A. C. 1933. The Theory of Unemployment. London: Macmillan.

Phillips, A. W. 1958. The Relation Between Unemployment and the Rate of Change of Money Wage Rates in the United Kingdom, 1862-1957. Economica. 25 (Nov): 283-99.

Presley, J. R. 1986. Negative Reactions in Cambridge to Keynes's General Theory. Eastern Economic Journal. 12.4: 385-96.

Robertson, D. H. 1915. A Study of Industrial Fluctuation. London: P. S. King.

Robertson, D. H. 1931. Economic Fragments. London: P. S. King. 
Robertson, D. H. 1963. Lectures on Economic Principles. London: Fontana.

Robinson, J. 1937a. Essays in the Theory of Employment. London: Macmillan.

Robinson, J. 1937b. Introduction to The Theory of Employment. London: Macmillan.

Robinson, J. 1951-1980. Collected Economic Papers. Vols. I-V. Oxford: Basil Blackwell. Cambridge, MA: MIT Press.

Robinson, J. 1952. The Rate of Interest and Other Essays. London: Macmillan.

Robinson, J. 1956. The Accumulation of Capital. London: Macmillan.

Robinson, J. [1962a] 1964. Economic Philosophy. Harmondsworth: Penguin.

Robinson, J. 1962b. Essays in the Theory of Economic Growth. London: Macmillan.

Robinson, J. 1966. Economics: An Awkward Corner. London: Allen and Unwin.

Robinson, J. 1971. Economic Heresies. New York: Basic Books.

Robinson, J. 1974. Inflation and Stabilization: A Neo-Keynesian View. The Spectator. October 19, pp. 488-89.

Robinson, J. 1979. Employment and Inflation. Quarterly Review of Economics \& Business. 19.3: 7-16.

Robinson, J. and J. Eatwell. 1973. An Introduction to Modern Economics. London: McGraw-Hill.

Robinson, J. and F. Wilkinson. 1985. Ideology and Logic. In F. Vicarelli (ed.): Keynes's Relevance Today. London: Macmillan.

Rymes, T. K. 1989. Keynes's Lectures, 1932-35: Notes of a Representative Student. Ann Arbor: University of Michigan Press. 
Santomero, A. M. and J. F. Seater. 1978. The Inflation-Unemployment TradeOff: A Critique of the Literature. Journal of Economic Literature. 16.2: 499-544.

Solow, R. M. 1976. Down the Phillips Curve with Gun and Camera. In D. A. Belsley et al (eds): Inflation, Trade and Taxes. Columbus: Ohio State University Press.

Viner, J. 1936. Mr. Keynes on the Causes of Unemployment. Quarterly Journal of Economics. 51 (Nov): 147-67.

Wicksell, K. [1898] 1936. Interest and Prices. London: Macmillan.

Young, W. 1987. Interpreting Mr Keynes: The IS-LM Enigma. Cambridge: Polity Press. 



\section{SCHRIFTENREIHE DES \\ PROMOTIONSSCHWERPUNKTS \\ MAKROÖKONOMISCHE DIAGNOSEN UND THERAPIEN \\ DER ARBEITSLOSIGKEIT}

Nr. 1/1998 Bernhard Holwegler und Hans-Michael Trautwein, Beschäftigungswirkungen der Internationalisierung, eine Studie aus- und einfließender Direktinvestitionen der Metall- und Elektroindustrie im Raum Stuttgart

Nr. 2/1998 Heinz-Peter Spahn, Heterogeneous Labour, the Unemployment Equlibrium, and the Natural Rate

Nr. 3/1998 Philip Arestis, Iris Biefang-Frisancho Mariscal and Harald Hagemann, Capital Shortage Unemployment in Germany and the UK

Nr. 4/1999 Theo Schewe, Full Employment in the Age of Globalisation? Political-Economic Analysis of Effective Employment Policies in the Nineties. The Case of Norway.

Nr. 5/1999 Hagen Krämer, Dienstleistungen: Motor für Wachstum und Beschäftigung in Deutschland?

Nr. 6/1999 Jürgen Kromphardt, Lohnbildung und Beschäftigung

Nr. 7/1999 Ewald Walterskirchen, Beschäftigungspolitik in Österreich

Nr. 8/1999 Reiner Franke, Lohnzurückhaltung, Beschäftigung und (zu) einfache empirische Zusammenhänge

Nr. 9/1999 Peter Kalmbach, Implications of Integration for Wage Formation and Employment 
Nr. 10/2000 Arne Heise, Theoretische Grundlagen einer Verhaltensabstimmung der makroökonomischen Politikträger

Nr. 11/2000 Eckhard Hein und Carsten Ochsen, Monetary Interest Rates, Income Shares, and Investment: Theory and Empirical Evidence for France, Germany, the UK, and the USA

Nr. 12/2000 Guntram R. M. Hepperle, Airbus - ein gelungenes Beispiel für beschäftigungsorientierte Industriepolitik?

Nr. 13/2000 Bernhard Holwegler, Implikationen der Technologiediffusion für technologische Arbeitslosigkeit

Nr. 14/2000 Markus Schreyer, Wachstum und Beschäftigung vor dem Hintergrund des Solowschen Produktiviätsparadoxons

Nr. 15/2000 Mauro Boianovsky, Some Cambridge Reactions to The General Theory: David Champernowne and Joan Robinson on Full Employment 